\title{
Die geheim van die prediking: In-stemming met die gemeente ${ }^{1}$
}

\author{
Johan Cilliers \\ Departement Praktiese Teologie en Missiologie \\ Universiteit van Stellenbosch
}

\begin{abstract}
The secret of preaching: Tuning in to the congregation

This paper concentrates on the role of the congregation in the process of preaching, contending that true contextualisation can only take place when the congregation fulfills its role as carrier and protector of the truth. It advocates the development of an ecumenical and hermeneutical approach to preaching, which not only implies a dialogue with the congregation of the present, but also of the past. The paper takes a brief look at certain homiletical trends in this regard, and puts forth three contours of contextualisation: (a) the continual translation of the language of Scripture, (b) the contemporary adaptation of the form of preaching, and (c) the nurturing of a congregational-hermeneutical culture.
\end{abstract}

\section{INLEIDING}

"Die Woord van God kan nooit losgemaak word van die volk van God nie." Met hierdie skerpsinnige formulering vra Luther opnuut ons aandag vir 'n prinsipiële verhouding, wat ook vir die homiletiek van deurslaggewende belang is (vgl Meuser 1983:112). Dit benadruk die feit dat dit in die prediking van die Woord van God handel om die volk van God, om die gemeente wat versamel is om die Woord te hoor. Luther se opmerking impliseer selfs dat die wyse waarop die Woord van God na die gemeente toe kom, wesenlik deur die realiteit van die gemeente beïnvloed word. Hierdie (homiletiese)

\footnotetext{
1 Uitbreiding van 'n referaat gelewer by 'n Buvton-byeenkoms oor Liturgie en Prediking: Stellenbosch 13 Augustus 2001
} 
verhouding, hierdie wisselwerking tussen teks en gemeente word raak deur Tom Long (1989:45) beskryf:

\begin{abstract}
We go to scripture, then, not to glean a set of facts about God or the faith that can be announced whenever and wherever, but to encounter a Presence, to hear God's voice speaking to us ever anew, calling us in the midst of the situations in which we find ourselves to be God's faithful people. The picture of the preacher sitting alone in the study, working with a biblical text in preparation for the sermon, is misleading. It is not the preacher who goes to the scripture; it is the church that goes to the scripture by means of the preacher. The preacher is a member of the community, set apart by them and sent to the scripture to search, to study, and to listen obediently on their behalf. So the preacher goes to the scripture, but not alone... The preacher explores the scripture, faithfully expecting to discover the truth of God's claim there and always willing to be surprised by it. Those who have sent the preacher have questions and concerns, and sometimes the text will speak directly to those questions. The text may, however, call those questions into question.
\end{abstract}

Die teks behoort dus nie aan die prediker nie. Net so min as wat ' $\mathrm{n}$ aarts-individualis, wat nie "ons" kan spel nie, die reg het om 'n plek op die kansel vol te staan. Die Bybelse teks behoort aan die gemeente, en moet as 't ware van lidmaat na lidmaat aangegee word om van alle kante bekyk en beluister te word, totdat almal saam kan stem, en sê: ons het God se stem gehoor. Om te preek is nié om 'n teologiese diktator, of 'n gevleuelde orator, of 'n heilige askeet te wees wat buitekant of bokant die gemeente wil leef nie; dis eerder om in-stemming met die gemeente rondom 'n Bybelteks te vind. Want: "Die Woord van God kan nooit losgemaak word van die volk van God nie.”

\title{
2. DIE STEM VAN DIE GEMEENTE
}

\subsection{Die gemeente: draer en beskermer van die waarheid}

Die geheim van die prediking het te make met die stem van die prediker en die stem van die Bybelteks. Daar hou dit egter nie op nie. Die spiritualiteit van 'n prediker blyk nie 
net uit sy of haar verhouding tot God of uit die omgang met die Bybelteks nie, maar ook uit die verhouding tot die gemeente, uit die wyse waarop die prediker na die stem van die gemeente luister. Die klassieke vergelyking moet dus ook hier uitgebrei word: lex orandi, lex credendi, lex vivendi, lex convivendi, lex praedicandi (soos jy bid, so bely jy, so leef jy, so leef jy saam, so preek jy). Oor hierdie convivendi, in hierdie geval, die saamleef met, en luister na die gemeente en die implikasies daarvan vir die prediking, handel dit hier.

Die stem van die gemeente móét eenvoudig in die preekmaakproses gehoor word. Die prediking is immers gerig op die gemeente, maar dit kom ook op uit die gemeente. In 'n sin ís die prediking die gemeente se "eiendom", en nie die prediker se privaatbesit nie (Bluck 1989:33). Wie die Bybelse tekste bloot as individue wil lees, loop gevaar om eenogig te wees. Die teks is eenvoudig té diep, té ryk, té multidimensioneel om slegs deur één na regte gelees te word. Daar is meer as een waarheid, meer as een gesig van God in elke teks, meer as wat een oog kan bevat. Daarom het die prediker die baie oë van die gemeente nodig, moet sy of haar uitleggers - en verkondigingsvoorregte verruim word om die gemeente in te sluit.

Maar, lei die klem op die veelheid van waarhede en insigte nie tot relativisme nie? As daar baie waarhede is, beteken dit dat daar nie één waarheid is nie? Nee, nie noodwendig nie. Elke teks moet in sy veelkleurigheid teen die fundamentele teks van die Skrif gelees word, vind sy samehang in hierdie fundamentele teks. Die vraag is natuurlik: wie bepaal wat hierdie fundamentele teks is?

Op 'n eerste vlak sou ons moes sê: nie net individuele uitleggers soos predikante en teoloë nie. Die Bybel is die Boek van die kerk, in die breedste sin van die word. Dis hier waar die hermeneutiek van ekumenisiteit sy funksie het: my siening van die fundamentele teks, en elke ander teks, moet ek saam met, en deur die pyn van ander lees, altyd met twee grondreëls in gedagte: eerstens, dat my perspektief niemand anders mag skade aandoen nie, en tweedens, dat ek self oop moet wees om te kan luister na die perspektief van ander, en gewillig moet wees om te verander. In dié sin kan die lees van die Bybelteks, en trouens van die hele preekmaakproses nie as 'n uitsluitlik individualistiese handeling of teologiese privaatbesit van die predikant beskou word nie. 
'n Ekumeniese hermeneutiek funksioneer daarby ook nie net in wydte nie, maar ook in diepte: dit het 'n oog vir die werking van dié spesifieke teks in die kerkgeskiedenis; dit luister na die eggo's van hierdie teks se werkingsgeskiedenis in die geskrifte en getuienisse van die kerkvaders en kerkmoeders. 'n Ekumeniese hermeneutiek kan nooit vaderloos en moederloos wees nie, en daarom ook nie weeskinder-preke baar nie. Dit staan in 'n ryke tradisie wat ons van teologiese arrogansie bewaar, en ons telkens herinner aan die troos en aansporing van die groot skare van geloofsgetuies wat rondom ons is ( $\mathrm{vgl} \mathrm{Heb} \mathrm{12:1).} \mathrm{Wie} \mathrm{ekumeniese} \mathrm{hermeneutiek} \mathrm{wil} \mathrm{beoefen,} \mathrm{word} \mathrm{nederig.}$ Luther het blykbaar op 'n papiertjie kort voor sy dood geskryf: Niemand kan die Skrif verstaan as hy nie 'n honderd jaar saam met die apostels en profete die kerk regeer het nie...

Die gemeente is die draer en beskermer van die waarheid (1 Tim 3:15). Die prediking begin en eindig nie met die preekmoment nie; die gemeente gaan die prediking vooraf en volg dit na met 'n Amen! Maar hierdie amen is nie die einde van die preek nie, eerder 'n nuwe begin - sò, dat die gemeente sélf nou predikers word in 'n wêreld wat wag om die evangelie te hoor. Die preekmaakproses moet daarom van begin tot einde, van die voorbereiding tot die aanbieding tot die nawerking van die preek, deur die gemeente prinsipieël mede-bepaal word. Predikers moet die rykdom, die homiletiese potensiaal wat daar in die gemeente steek, raaksien en benut. Trouens, van die beste kommentaar op die prediking vind predikers nie net op hulle boekrakke nie, maar ook in die murg en bloed, in die weefsel, ja in die konteks van die gemeente wat rondom die prediking lééf.

Dit vra dat predikers met nuwe oë na gemeentes sal kyk, dat hulle 'n teologiese sleutel sal hanteer as hulle die hartsgeheime van die gemeente wil ontsluit. Dat hulle diégene wat in die erediens kom, teologies sal beoordeel, dit wil sê as mense met wie God lankal reeds werksaam is, mense vir wie Christus gesterf het en opgewek is, mense vir wie God se genade daarom genoegsaam is. Dat hulle diégene wat in die kerkbanke sit, as gawes van God sal sien, eerder as godsdienstige kliënte wie se belange so goed as moontlik gehanteer moet word. Maar, wat beteken dit alles vir die preekmaakproses? Die opmerkings van Karl Barth in dié verband spreek van wysheid. Hy groepeer dit in vyf gedagtegange - verkort hier weergegee: 
- Die prediker moet sy of haar gemeente liefhê, en een met hulle wees. Die grondhouding moet een wees van: Hierdie is my mense en ek wil met hulle deel wat God aan my gegee het. Al is jy ook hòè welsprekend, al praat jy beter as engele, sonder liefde baat dit niks...

- Omdat die prediker die gemeente liefhet, moet hy of sy die lewe van die gemeente leef, op hulle vlak. Die prediker hoef nie noodwendig die slimste persoon onder die mense te wees, of die dorpswaarseêr wat die mees verborge gedagtes van mense kan blootlê nie, maar die vraag wat hulle diepste gedagtes werklik is, moet altyd op die prediker se hart druk.

- Die prediking is nie bloot 'n helderder en meer adekwate verduideliking van wat die betekenis van die lewe is, te midde van ander verduidelikings nie - alhoewel dit nie onbelangrik is nie - maar eerder 'n plasing van die betekenis van die lewe binne die lig van God se openbaring.

- Om te preek, is om taktvol te wees! Is om te weet wat om wanneer vir wie te sê. Wanneer daar wel Bybelse en profetiese kritiek uitgespreek moet word, mag dit alleen in 'n nederige en gewyde gees geskied - dit is nie nodig om 'n afgod van die waarheid te maak nie.

- Om te preek, is om bewus te wees van die oomblik, van die uur waarin beide prediker en gemeente verkeer. Dis om te vra: watter eise stel die kontemporêre situasie aan die prediker en gemeente? Immers, beide prediker en gemeente deel dieselfde historiese ervaring; daarom moet die woorde van die prediker relevant wees vir die onmiddellike belange van die hoorders. As dìt verstaan word, sal predikers beter op hulle hoede kan wees teen 'n onophoudelike diskoers oor temas wat lankal hulle relevansie verloor het (1964:96-97).

Dit onderstreep die feit: predikers moet by hulle gemeentes wéés, nie op 'n ander (teologiese, sosiologiese, kosmologiese) planeet nie. Dit sal waarskylik aanpassings in die preekmakprogram van die prediker vra, asook die skep van geleenthede en strukture waarbinne die insette van die gemeente op die beste wyse tot hulle reg kan kom. Dit vra dat die prediker sy of haar gemeente meer dikwels rondom die preekteks in die oë sal 
kyk, en hulle stem hieroor sal hoor, dat ons preekstoele meer soos ronde tafels moet begin lyk (die titel van Mc Clure se boek: The roundtable pulpit, 1995)

Predikers mag só 'n paradigma-skuif dalk as bedreigend ervaar. Trouens, dikwels ontmoedig predikers enige inbraak op hulle sisteem, omdat hulle diep binne-in hulleself weet dat daar fout met hierdie sisteem is. Om só uit jou veilige hawe gehaal te word, kan egter juis verrykend wees. Rudolf Bohren (1971:521-522) haal die prediker Franz Jantsch in dié verband aan:

'n Vrou het een keer my preek oor die huweliksliefde onderbreek en my toegeroep: "Dominee, dit hou ek nie uit nie. Ek protesteer." Ek het daarop ingegaan deur 'n wyse man uit die gemeente te vra om hierop te reageer. Toe neem ander ook aan die gesprek deel, en die standpunte word verhelder. Ek was nie kwaad vir die vrou nie, inteendeel. Sy het verskoning gevra dat haar temperament die oorhand verkry het, maar dié voorval het op die gemeente 'n groot indruk gemaak.

Dis sekerlik nie aan te bevel dat elke preek op hierdie wyse onderbreek moet word nie, maar hierdie tussenwerpsel van die vrou is 'n gekonsentreerde voorbeeld van wat 'n gemeentegesprek kán wees. Die Gees is immers nie net aan die predikant gegee nie, maar aan die gemeente. Die charisma van die predikant is goed, maar die somtotaal van gawes wat die Gees aan die gemeente gegee het, is beter.

Ons kan nie hiervan wegkom nie: Die prediking is wesenlik 'n gemeentelike, en dus kontekstuele aangeleentheid. Daarom sal ons, nie alleen omdat dit teologies belangrik is nie, maar ook kommunikasiewetenskaplik gesproke essensieël, telkens moet leer om die invoer en terugvoer van die gemeente rondom die prediking te fasiliteer. Dit blyk 'n belangrike veld vir verdere ondersoek te wees.

\subsection{Teks en konteks}

Hierdie gerigtheid op die gemeente met haar eie konteks, impliseer onder andere dat die prediking ' $n$ eietydse en aktuele karakter verkry. Dit kan immers nie anders nie: Die gemeente bring die wyer kontekste waarin die prediking afspeel (sosio-ekonomies, polities, ekologies, eties, ens.) in die spel van die preekmaakproses. Daarsonder kan die 
prediking nié; kontekstualiteit is nie 'n luukse nie, dit behoort tot die wese van die prediking. Die lewende Woord kom altyd tot die mens van die hede (vgl die titel van die proefskrif van Müller 1961). Die vraag is nie óf daar kontekstualisering moet plaasvind nie, alleen maar: hoe? Hierin gaan die Skrif ons self voor: dit is altyd 'n Woord-inkonteks, 'n vleesgeworde Woord, histories en kontemporêr. Die uitdaging van die prediking is om in die na-spreke van die teks ook die konteks in die teks na te loop, en dit dan te vertaal in terme van die dinamiese ekwivalent vir die eie tyd (vgl Müller s j 134-135).

Dié kontekstualisering van die evangelie bly egter een van die moeilikste opdragte aan die prediker. Dit vra teologiese volwassenheid en sensitiwiteit, vra dat die prediker niks anders nie as die evangelie (en nie 'n afgewaterde reduksie daarvan nie) in die konteks laat inkarneer, dit werklik die vlees en bloed van die eie tyd laat aanneem (vgl die studie van Webb 1998) Hier moet ons veral ligloop vir preekverskynsels en -vorme wat op die oog af kontekstueel lyk, maar ten diepste juis 'n verleentheid met die eis van kontekstualiteit verraai. Eietydse cliché's, aktuele stopwoorde en die lukrake invoer van "sake van die dag" is nie noodwendig gelyk aan werklike kontekstualisering nie. Elke preek hoef ook nie, kàn ook nie tot in alle detail kontekstualiseer nie. Wat nodig is, is eerder dat die regte, dieperliggende eksistensiële vrae in die preekmaakproses aan die orde kom, en dat die prediker dus werklik na mense in hulle konteks sal luister, sò sal luister dat die prediking hulle tot geestelike volwassenheid en teologiese onderskeidingsvermoë, ja tot wysheid in die Bybelse sin van die word kan begelei. Juis daarom kan die prediking nooit 'n eenmalige reseppie bied nie, maar dra dit eerder oor 'n lang tyd by tot die kweek van 'n lewenshouding, 'n bestaan in wysheid voor God.

Dikwels meen predikers dat hulle mense ken, dat hulle alles van mense se situasies af weet, maar meestal is dit nie die geval nie. Kontekstualisering vra tyd, vra aandag en sensitiwiteit. Nie alleen moet die pad na die teks verlangsaam word nie, maar ook die pad na die hart van die gemeente. Geen wonder nie dat die opdrag om te kontekstualiseer dikwels maar eerder in die prediking vermy word nie.

Maar, ons kán die roeping om die evangelie ook in die prediking te kontekstualiseer, nie systap nie. Ons moet mense tref waar hulle ìs, of ons mis hulle. Die vraag na die verhouding tussen teks en konteks (of God en mens) begelei die prediking, en trouens die breë spektrum van teologiese loci al van die begin af. Die preek is soos 'n 
spantou tussen die twee punte van die boog - as een kant nie vas is nie, kan die pyl nie vlieg nie! Dié spanning duik telkens weer op - soos ook in resente homiletiese literatuur. 'n Goeie voorbeeld is die twee hoofreferate wat tydens die konferensie van die Societas Homiletica in Washington (1999) gelewer is. Die tema was: Preaching grace in the human condition, en die twee sprekers het breedweg gesproke die twee punte van die boog verteenwoordig. Mary Catherine Hilkert ('n Rooms-Katolieke teoloog) het 'n sterk saak daarvoor uitgemaak - oorvereenvoudig gesê - dat ons in die prediking primêr moet uitgaan van die toestande van menslike ellende, om daar te soek na tekens van God se teenwoordigheid, en hulle dan aan te wys en te benoem as genade, as eggo's van die evangelie. Sy het dan ook 'n boek geskryf met die titel: Naming Grace. Preaching and the sacramental Imagination (1998), waarin sy as 't ware twee teologiese balle in die lug wil hou. Aan die een kant: "Contemporary human experience can disclose new dimensions in the story of Jesus." En, tegelykertyd: "The Gospels and the history of Jesus limit and focus the contemporary retelling of the story." (55)

Charles Campell was die ander hoofspreker. Weereens ongenuanseerd gesê: Campell neem as uitgangspunt "Preaching Jesus" (ook die titel van sy boek, 1997). Volgens sy oortuiging kom God ook deur die prediking die toestand van menslike ellende binne en vra daar om gehoor en gehoorsaam te word. Hy sluit as post-liberale denker aan by Hans Frei, en sê onder andere: "For Frei the starting point is not human experience or existence, but rather the specific, unsubstitutible identity of Jesus Christ, which is rendered in the interplay of character and incident in the gospel narratives." (57). Hy ontwerp dan verder 'n model vir narratiewe prediking as teenvoeter vir prediking wat op 'n kognitiewe-proporsionele wyse óf met die Bybelteks, óf Christelike temas en dogmas óf die Christelike tradisie omgaan.

Verskeie ander homilete beoefen hulle teologie presies binne hierdie spanning. Leonora Tubbs Tisdale het byvoorbeeld 'n boek geskryf met die provokatiewe titel Preaching as local theology and folk art (1997). Sy bied onder andere sewe weë aan waarvolgens die gemeente geëksegetiseer kan word om kontemporêre prediking te verseker. Stephen Farris betitel sy boek: Preaching that matters (1998), en hy worstel met presies dieselfde spanning: om analogieë tussen die wêrelde van die teks en die gemeente te vind (hy stel ses stappe voor), en so sou ons op die homiletiese ry kon afgaan 
(vgl bv ook E Jonker 1998: Van verstaan naar vertolken; ook die interessante boek van Schreiter 1986: Constructing Local Theologies). Dit is in elk geval belangrik dat teenoorgestelde eksponente met mekaar in gesprek bly en nie te gou 'n kompromis bereik nie. Daarvoor is daar teologies en eksistensieël te veel op die spel (vgl Bos 1999: 245).

\subsection{Kontoere van kontekstualisering}

Die volgende is na my mening hier van belang:

- Dit behoort tot die wese van die prediking om telkens die taal van die Skrif vir die tyd te herformuleer. Daarmee word die moederspraak van die teks nie prysgegee nie, maar juis in haar volle konsekwensies deurgetrek. Die taak van die prediking slaan hier na twee kante toe: om die gemeente opnuut hulle egte moedertaal te leer, én hulle te begelei in die eietydse herformulering daarvan. In die prediking kàn ons nie anders nie as om lokale teologieë te vorm of te help vorm, en self daardeur gevorm te word nie. Prediking kan sò "Bybels" in taal en idioom wees, dat dit helaas onverstaanbaar vir konkrete mense van 'n spesifieke tyd word. Jy kan só "korrek" wees, dat jy verkeerd is. Soms moet minder korrektheid (Cicero noem dit "bestudeerde slordigheid") die weg open tot verstaanbaarheid - wat tog nou nie weer as 'n alibi vir algehele grammatikale of homiletiese slordigheid gesien moet word nie! Die punt is: die evangelie is verstaanbaar. Dit kom altyd tot mense hier en nou (hic et nunc). God het Hom aangepas in die idioom van die tyd (vgl. maar net die taal van die Bybel). Daarom kan die prediking ook nie anders as om verstaanbaar te wees nie wat egter weer nie beteken dat die kompleksiteit van die lewe oorvereenvoudig moet word nie. Die taal van Sion/Kanaan is in dié sin nie "heilig" nie. Dit neem eerder die kontoere van die tyd aan, inkarneer in die lokale gemeente en omgewing - en vind so sy doel. Kontekstuele prediking vra verstaanbare prediking, vra daarom 'n openheid vir die hartklop van die eietydse - wat jy dikwels op sy helderste in die kuns van die tyd (literatuur, films, ens) hoor. Van die grootste epifanieë wat 'n prediker kàn beleef, is in die kunsgalery of op straat (op die "markplein"), tussen gewone mense. Hierdie inkarnering van die woorde van die prediking in die eietydse, het uiteraard 
grense: die evangelie van die teks bly altyd 'n kontra-evangelie, wat as sodanig ook kontra dit wat gebruiklik of mode-van-die-tyd is, kan staan.

- Dit behoort ook tot die wese van kontekstuele prediking om die vorm daarvan voortdurend te heroorweeg. Die feit dat die Bybelse teks deurslaggewend is vir die vormgewing van die preek, beteken nie dat alle preke oor spesifieke tekste altyd dieselfde vorm moet hê nie. Benewens die kreatiewe vryheid wat die teks bied, vra die konteks ook telkens om 'n homiletiese ratwisseling, om verantwoordelike vormvariasie binne die kommunikatiewe strategieë wat aan die orde van die dag is (vgl die studie van Bluck 1989: Christian Communication Reconsidered: 32-43). Wel mag die vorm nooit 'n doel in sigself word nie, maar moet dit steeds diensbaar aan die verstaanbaarheid van die preek bly. Tegniek mag nooit oor die teks heers nie, en die aanleer van 'n aantal kommunikasiestrategieë mag nooit die arbeid aan, en invloed van die teks in die prediking op die agtergrond skuif nie. Jy kan nie - hoef nie - die Bybel met joernalistieke flair te probeer opkikker om dit "aktueler" en “lewendiger" te maak nie (Miskotte 1941:66). En tog lê hier 'n wêreld wat ontgin kan word. So 'n openheid vir die kommunikatiewe omgewing is niks nuuts nie. Dis welbekend dat Augustinus byvoorbeeld ryklik, en op die oog af gevaarlik baie, geleen het by die retoriese strategieë van Cicero. Hy het dit egter telkens aangepas by die aard van die teologie en ook die profiel van die mense van sy tyd (dalk sy bekendste: prediking as docere, delectare en movere: onderwysend, onderhoudend en oortuigend; vgl Den Dulk 1999: 15 e v). Die realiteit is: ons leef in 'n tyd waarin kommunikasie op radikale ander maniere plaasvind as tien of twintig jaar gelede. Die era van die rekenaar spoel oor ons heen. Binne die volgende vyf jaar gaan daar 'n ongekende ontploffing in die informasietegnologie plaasvind. Die prediking kàn nie anders nie as om ook hier inkarnerend teenwoordig te wees en die vrugte daarvan te geniet nie. Indien ons kommunikatiewe teorieë en - praktyke stol op 'n ewige gister, is die skrif aan die muur vir kontekstuele prediking, vandag. Verskeie resente homilete is diep onder die indruk hiervan en sluit byvoorbeeld doelbewus aan by heersende kommunikasiewetenskaplike en retoriese strategieë: Buttrick met sy Homiletic: Moves and structures (1987) is deurdronge daarvan. Hy benut onder 
andere eksplisiet die wyse waarop 'n goeie film die boodskap aan die kyker oordra wanneer hy praat van "opening, closing, association and disassociation moves" (294 e v). Die kamera word gebruik as analogie vir die wyse waarop ons waarneming - ook op neurologiese vlak - plaasvind, wanneer ons 'n prentjie "sien". Dit het 'n baie groter uitwerking as die blote inneem van steriele "inligting". So moet die een prentjie na die ander mekaar ook in die prediking in verskillende "moves" vaartbelyn opvolg, wat meewerk tot 'n holistiese en estetiese waarneming (vgl ook Cilliers 1998:119). Eugene Lowry - om nog 'n enkele naam te noem - werk met 'n tegniek wat al vroeër in die teaterwêreld ingevoer is (die sg Entfremdungstechnik): om die vreemde, die paradoksale van die (Bybelse) boodskap nie met allerhande vooropgesette vorms in die prediking te laat stol nie, maar om die verrassende daarvan juis enduit, ook in die vormgewing, te ontgin - ter wille van kommunikasiewetenskaplike kontekstualisering (1980:76 e v).

- Ten diepste gaan dit hier oor die hermeneutiese vaardighede van die prediker en gemeente. Wie nie prinsipieël hermeneuties dink nie, kan nie kontekstualiseer nie. In die prediking staan of val baie met die wyse waarop die prediker hom - of haarself in die sogenaamde "hermeneutiese sirkel", oftewel dialoog tussen teks en konteks, en uiteidelik ook in die gesprek tussen prediker, gemeente en God plaas. Bo is die dialoog 'n "spanning" genoem (soos die spantou van 'n boog). In 'n sekere sin ìs dit 'n spanning, wat nooit ontlont mág word nie. Teologie wat nie met paradokse werk nie, is futloos. Wie die relasie tussen teks en konteks té gou wil platstryk, demp die bruising van kreatiwiteit. Daarmee word nie gesê dat die Woord nie sélf die krag het om 'n spesifieke konteks binne te dring en te omvorm nie. Alles hang gelukkig nie af van die prediker se hermeneutiese briljantheid nie. Die Woord is immers as sodanig nooit tydloos nie, en word as swaard met twee skerp snykante nooit stompgemaak deur die muur van tydsgrense nie. Daarom is dit in 'n sekere sin 'n valse teenstelling as predikers vra: Moet ons by die teks, of by die situasie begin? God is lankal, ook via die teks, op pad na elke situasie toe. Daar ìs geen spanning nie, die pole is oorbrug; Christus is geïnkarneer, en die Gees is uitgestort. Dit ìs so. En tog hét die prediker 'n hermeneutiese roeping, 'n verantwoordelikheid om die dialoog tussen teks 
en konteks te dien, om juis hierdie koms van God na, en sy inwoning in die werklikheid aan die gemeente uit te wys (vgl Cilliers 1998: Die uitwysing van God op die kansel). Predikers is brugbouers, omdat die Brug gebou is. Hulle is onophoudelik op pad, heen-en-weer-reisigers tussen die wêreld van die teks en die wêreld van die konteks. Hulle is mense wat die vrae van die teks en die konteks voortdurend op mekaar laat instem, omdat die Gees die groot Instemmer is. Sonder hierdie instemming kan teks en konteks dalk by mekaar verbypraat. Ja, wie nie sy of haar hermeneutiese roeping vervul nie, kan gevaar loop om die "regte" teks vir die "verkeerde" tyd te preek, of die "verkeerde" teks vir die "regte" tyd! Predikers wat nie hermeneuties volwasse en sensitief is nie, kan tekste en waarhede belangriker begin ag as mense, of kan mense oor tekste en waarhede laat heers. Wanneer die hermeneutiek nie klop nie - wanneer teks en konteks mekaar mis - is valse profesie meestal die gevolg. Predikers lees dikwels die uur (van God se koms) verkeerd. Hulle is nie profeties betyds nie. Hulle hermeneutiese tydsberekening is uit. $\mathrm{O}$, hulle mag wel korrekte, tydlose waarhede verkondig, maar dis ontydig, en daarom vals. Gister se teologie verword in die valse profeet se mond tot vandag se ideologie. Karl Barth (1958:413) noem sulke mense gewoon dwase:

Dwase mense is altyd óf te vroeg óf te laat. Hulle slaap wanneer hulle wakker moet wees, en is wakker wanneer hulle moet slaap. Hulle swyg wanneer hulle moet praat en praat wanneer dit beter is om te swyg. Hulle lag wanneer hulle moet huil en huil wanneer hulle getroos behoort te wees en gerus maar kan lag. Hulle werk wanneer hulle moet bid en bid wanneer slegs werk die verskil kan maak. Hulle bedink alles op die verkeerde tyd; sê alles aan die verkeerde mense; doen alles in die verkeerde rigting; maak altyd weer 'n keuse vir die ingewikkelde, maar irrelevante dinge, terwyl die eenvoudige, maar noodsaaklike gevra word. Hierin lê die briljantheid van die dwaasheid.

Wat van ons as predikers in hiérdie uur gevra word, is wysheid. Dìt kan ons slegs leer op die skoot van die gemeente, wat die moeder van alle gelowiges is (Calvyn). 


\section{Literatuurverwysings}

Barth, K 1958. Church dogmatics 4/2. Edinburgh: T \& T Clark.

Barth, K 1964. Prayer and preaching. London: SCM.

Bluck, J 1989. Christian communication reconsidered. Geneva: WCC Publications.

Bohren, R 1971. Predigtlehre. München: Kaiser.

Bos, R 1999. Literatuur bij de preekvoorbereiding (uit: Postille 1999-2000) Zoetermeer: Uitgeverij Boekencentrum.

Buttrick, D 1987. Homiletic: Moves and structures. Philadelphia: Fortress.

Campbell, C 1997. Preaching Jesus: New directions for homiletics in Hans Frei's postliberal theology. Grand Rapids: Eerdmans.

Cilliers, J H 1998. Die uitwysing van God op die kansel: Inspirerende perspektiewe op die prediking - om God te sien en ander te láát sien. Kaapstad: Lux Verbi.

Den Dulk, M 1999. Leren preken met Augustinus. (uit: Postille 1999-2000) Zoetermeer: Uitgeverij Boekencentrum.

Farris, S 1998. Preaching that matters: The Bible and our lives. Louisville: Westminster/John Knox.

Hilkert, M C 1998. Naming grace: Preaching and the sacramental imagination. New York: Continuum.

Jonker, E 1998. Van verstaan naar vertolken: Een praktisch-theologische analyse van de voorbereiding van een preek of catechese over de Openbaring van Johannes. Groningen: Self uitgegee.

Long, T G 1989. The witness of preaching. Louisville, Kentucky: Westminster/John Knox.

Lowry, E L 1980. The homiletical plot: The sermon as narrative art form. Atlanta: John Knox.

Mc Clure, J 1995. The roundtable pulpit. Where leadership and preaching meet. Nashville: Abingdon.

Meuser F W 1983. Luther the preacher. Minneapolis: Augsburg.

Miskotte, K H 1941. Het waagstuk der prediking. Den Haag: DA Daamen's.

Müller, B A 1961. Die lewende woord aan die mens van die hede: 'n Bespreking van vrae rondom die aktuele woordverkondiging. Zaandijk: J Heijnis. 
Müller, B A sj. Die eksegetiese onderbou van die struktuur van die prediking, in Sol Iustitiae, 121-138. Kaapstad: NG Kerk-Uitgewers.

Schreiter, R J 1986. Constructing local theologies. New York: Orbis.

Tisdale, L T 1997. Preaching as local theology and folk art. Minneapolis: Fortress.

Webb, J M 1998. Preaching and the challenge of pluralism. St Louis: Chalice. 